\title{
Bir olgu nedeni ile akut infantil hemorajik ödem
}

\author{
Case report: acute hemorrhagic edema of infancy \\ Demet Alaygut*, Suar Çakı Kılıç, Osman Gülsever, Hilal Topçu Gavas, Pelin Kekeç \\ Bostanci
}

Çocuk Sağlığı ve Hastalıkları Anabilim Dalı (Yrd. Doç. Dr. D. Alaygut, Yrd. Doç. Dr. S. Ç. Kılıç, Dr. O. Gülsever, Dr. H. T. Gavas, Dr. P. K. Bostancı), Cumhuriyet Üniversitesi Tıp Fakültesi, TR58140 Sivas

\begin{abstract}
Özet
Akut infantil hemorajik ödem (AİHÖ), iç organ tutulumu olmaksızın, cilde sınırlı bir lökositoklastik vaskülittir. Ödem ve purpurik lezyonlar hastalığı karakterize eder. İki yaş altında ortaya çıkan kutanöz vaskülitin nadir bir formu olarak düşünülmektedir. Bir çok yazar tarafindan Henoch Schönlein Purpurası ile histopatolojik ve nedensel benzerlikler taşıdığı kabul edilir. Gürültülü başlangıcına rağmen, gidiş selimdir ve birkaç hafta içerisinde spontan iyileşme görülür. Etyolojisi bilinmemekle birlikte, AİHÖ sıklıkla enfeksiyonlar, ilaç kullanımı ve aşılamayı takip eder. Burada, sağ yanağında purpurik plak şeklinde döküntü ve yüzde ve gözde ödemle başvuran ve klinik olarak AİHÖ tanısı almış on aylık kız olgu sunulmaktadır.
\end{abstract}

Anahtar sözcükler: Akut infantil hemorajik ödem, infant, olgu sunumu

\begin{abstract}
Acute infantile hemorrhagic edema (AIHE) is a leukocytoclastic vasculitis that is confined to the skin without visceral involvement. Edema and purpuric lesions characterize the disease. It is considered as an uncommon form of cutaneous vasculitis occurring in children younger than 2 years of age. By many authors, it is considered to be a variant of Henoch Schönlein Purpura because of similarities in causality and histopathology. In spite of its clinical violent onset, the course is often benign and spontaneous recovery is observed within several weeks. Although the etiology is unknown, AIHE often follows infections, drug treatment or vaccination. Here, a tenmonth-old girl presenting with purpuric plaques on the right buccal area and edema on the face and eye and clinically diagnosed as AIHE is presented.
\end{abstract}

Keywords: Acute infantile hemorrhagic edema, infant, case report

Geliş tarihi/Received: 17 Aralık 2012; Kabul tarihi/Accepted: XX Aralık 2013

*iletişim adresi:

Dr. Demet Alaygut, Çocuk Sağlığı ve Hastalıkları Anabilim Dalı, Cumhuriyet Üniversitesi Tıp Fakültesi, TR-58140 Sivas. E-posta: Email: demetalaygut@yahoo.com

Giriş

Akut infantil hemorajik ödem (AİHÖ), ilk olarak 1913 y1lında Snow tarafindan tanımlanmış akut kutanöz lökositoklastik vaskülittir. Genellikle 4-24 ay arası çocuklarda görülen nadir bir hastalıktır [1]. Klinik olarak sıklıkla yanaklarda, kulak kepçesinde ve ekstremitelerde genellikle çapları $1-5 \mathrm{~cm}$ arasında değişebilen madalyon benzeri hemorajik purpuralara ödem eşlik eder [2]. Deri lezyonları başlangıçta tek tek ancak zamanla birleşme eğiliminde olan yuvarlak, hemorajik papül ve plaklar şeklindedir. Histopatolojik görünüm tipik lökositoklastik vaskülit bulgularını yansıtır. Hastalığın etyolojisi bilinmemektedir [3]. Ancak postenfeksiyöz, ilaç alımı ve immunizasyon ile ilgili olabileceği bildirilmiştir [4]. Hastalığın en tipik özelliği olan lezyonların ve ödemin dramatik görünümüne karşın genel durum daima iyidir ve hasta kendiliğinden düzelir [1]. AİHÖ, Henoch Schönlein purpurası (HSP), purpura fulminans, septisemi, 
meningokoksemi gibi purpurik döküntülerin ayırıcı tanısında düşünülmelidir. Bu yazıda kliniğimizde AİHÖ̈ tanısı alan 10 aylık kız hasta sunulmuştur.

\section{Olgu sunumu}

On aylık kız hasta sağ yanakta şişlik ve döküntü yakınması ile başvurdu. Başvurusundan bir gün önce yanağında sinek 1sırığı şeklinde bir döküntünün ailesi tarafindan fark edildiği öğrenildi. Yakın zamanda aşılama öyküsü yoktu. Öz ve soygeçmişinde özellik olmayan hastanın fizik muayenesinde sağ yanakta ödem ve annüler tarzda döküntü saptandı (Resim 1-2). Diğer sistem muayeneleri normal sınırlardaydı.

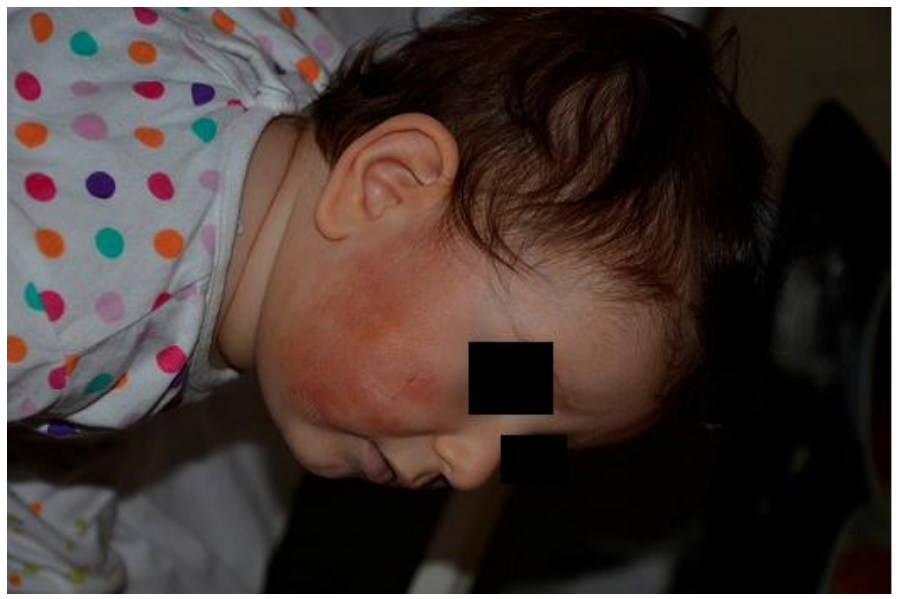

Resim 1. Hastanın başvuru anında sağ yanağa lokalize purpurik döküntü.

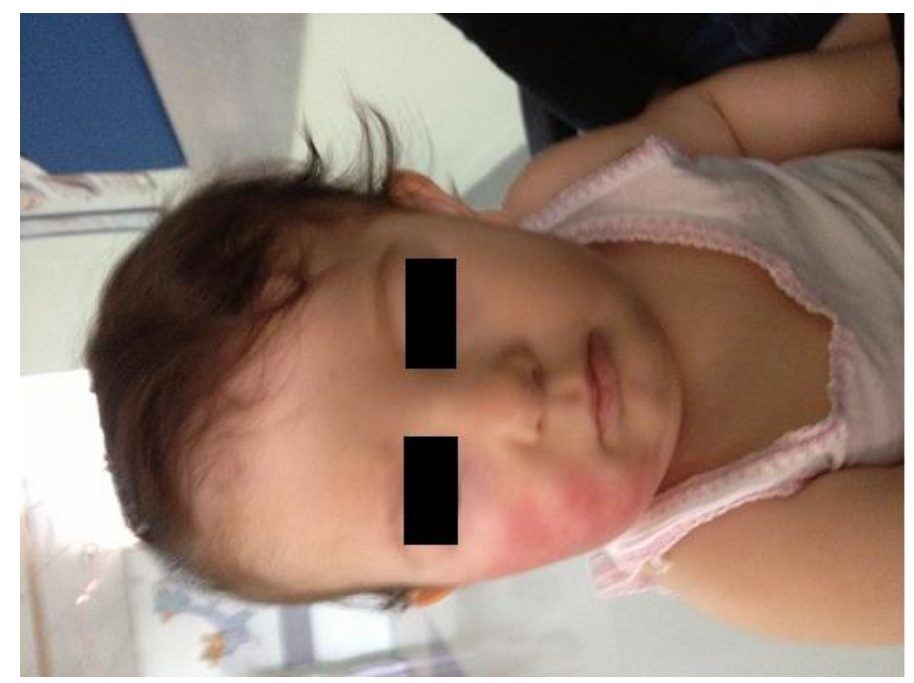

Resim 2. Yüzde ödem.

Tam kan ve idrar tetkiki, rutin biyokimya, eritrosit sedimentasyon hızı (ESH), C-reaktif protein, koagülasyon testleri normal bulundu. Serum immunglobulin düzeyleri, C3, C4, ANA, ASO değerleri normal sinırlardaydı. Etyolojiye yönelik gönderilen HAV, HBV, HCV, HIV, EBV, CMV, Parvo virüs ve Mycoplasma pneumoniae'ye yönelik tetkiklerinde aşılanmaya bağlı anti-HBs pozitifliği dışında özellik saptanmadı. Olguya destek tedavisi verildi. Genel durumu iyi olan ve takipte deri lezyonları 7 gün içerisinde gerileyen olgu taburcu edildi. 


\section{Tartışma}

AİHÖ, derinin lökositoklastik vasküliti olup klinikte kendini ateş, geniş purpurik deri döküntüleri ve ödem ile gösterir ve gürültülü bir başlangıç, selim bir gidiş ve klinik olarak spontan iyileşme gösterir [5]. Daha çok 4-24 ay arası çocuklarda özellikle yüz, kulaklar ve ekstremitelerde hedef tahtası görüntüsü, madalyon benzeri purpura ve ödem gibi cilt lezyonları ile karakterizedir [2].

Etyoloji halen bilinmemekle birlikte bazı hastalarda yakın zamanda geçirilmiş viral ve bakteriyel enfeksiyon (özellikle üst solunum yolu enfeksiyonu), ilaç alımı ve/veya aş1lama öyküsü rapor edilmiştir [4]. Vakamızda öykü, fizik muayene ve laboratuvar tetkikleri ile etyoloji saptanamamıştır.

AİHÖ tanısı için spesifik laboratuar bulgusu bulunmamaktadır. Ancak lökositoz ve hafif artmış ESH olabilir [1]. Hastalığın inflamatuar özelliği dikkate alındığında trombositoz gözlenebilir. Tam kan sayımı, temel koagülasyon testleri ve idrar tetkiki ayırıcı tanıda düşünülmesi gereken bir çok tanıyı dışlamaya yeterli olmaktadır.

Histopatolojik olarak immun kompleks ilişkili akut kutanöz lökositoklastik vaskülit saptanır. Saraçlar ve ark. [6] immunfloresan inceleme ile sırası ile fibrinojen, C3, IgG, IgM, Ig A, Ig E gibi çeşitli immun depolanmalar göstermişlerdir. Hastaya mevcut yaşı, kliniği ve laboratuvar bulguları göz önünde bulundurularak, mukozal ve iç organ tutulumu da olmaması nedeniyle AİHÖ tanısı konuldu. Ailenin istememesi nedeni ile deri biyopsisi yapılamadı. AİHÖ bazı yazarlar tarafından nedeni ve histopatolojisindeki benzerlik nedeni ile HSP'nin bir varyantı olarak kabul edilmektedir. Her ikisi de ani hemorajik döküntülerle başlar ve polimorfik cilt lezyonları olur. Ancak HSP'de yüz genellikle korunur. AİHÖ'de hasta yaşı küçük, atak süresi kısa ve tekrarlama oranı düşüktür. HSP'de ise atak süresi uzun, intestinal ve renal tutulum gibi ciddi komplikasyonlar vardır [5]. Ancak AİHÖ'de de bildirilen iki intussusepsiyon vakası vardır ve bunlardan biri fatal sonuçlanmıştır [7]. Ancak AİHÖ'nün ayrı bir antite olarak kabul edilmesi gerektiğini belirten yazılar da vardır [8].

AİHÖ’nün spesifik tedavisi bulunmamaktadır ve tartışmalıdır. Bazı yazarlar steroid ve antihistaminik tedavisinin kullanımının düzelme için gerektiğini bildirmişlerdir [6]. Ancak bir kısım yazarlar da hastalığın kendi doğal seyri ile iyileştiğini, steroid ve antihistaminiklerin hastalığın klinik seyrini değiştirmediğini bildirmektedirler. Prognozu genellikle iyidir. Kendiliğinde düzelme 1-3 hafta içerisinde gerçekleşmektedir ancak bu sürenin 35 güne dek uzayabileceği bildirilmiştir [8]. Bu vakada sadece destek tedavisi verilmiş, steroid ve antihistamik kullanılmamış ve lezyonlar 7 gün içerisinde düzelmiştir. Ancak etyolojide bakteriyel enfeksiyon düşünülüyorsa antibiyotik, aurikular ve kartilaj yap1 etkilenmiş ise nonsteroid anti inflamatuvar ilaçlar verilebilir [9].

Sonuç olarak, AİHÖ, infant döneminin selim, kendiliğinden düzelen ve tedavi gerektirmeyen bir hastalığıdır. Nadir olmadığı düşünülmektedir. Diğer döküntülü hastalıklarla kolayca karışabilir, bu nedenle iyi tanınmalıdır. Böylece gereksiz tedavi ve endişenin ortadan kalkacağı düşünülmektedir.

\section{Kaynaklar}

1. Karremann M, Jordan AJ, Bell N, Witsch M, Dürken M. Acute hemorrhagic edema of infancy: report of 4 cases and review of the current literature. Clin Pediatr 2009; 48: 323-6.

2. Dönmez O, Memeşa A. Akut infantil hemorajik ödem: Üç olgunun takdimi. ADÜ Tip Fakültesi Dergisi 2001; 2: 31-3.

3. Baselga E, Drolet BA, Esterly NB. Purpura in infants and children. J Am Acad Dermatol 1997; 37: 673-705.

4. Di Lernia V, Lombardi M, Lo Scocco G. Infantile acute hemorrhagic edema and rotavirus infection. Pediatr Dermatol 2004; 21: 548-50. 
5. Caksen H, Odabaş D, Kösem M, Arslan S, Oner AF, Ataş B, Akçay G, Ceylan N. Report of eight infants with acute infantile hemorrhagic edema and review of the literature. J Dermatol 2002; 29: 290-5.

6. Saraçlar Y, Tinaztepe K, Adalığlu G, Tuncer A. Acute hemorrhagic edema of infancy (AHEI)--a variant of Henoch-Schönlein purpura or a distinct clinical entity? J Allergy Clin Immunol 1990; 86: 473-83.

7. $\mathrm{Yu}$ JE, Mancini AJ, Miller ML. Intussusception in an infant with acute hemorrhagic edema of infancy. Pediatr Dermatol 2007; 24: 61-4.

8. Legrain V, Lejean S, Taïeb A, Guillard JM, Battin J, Maleville J. Infantile acute hemorrhagic edema of the skin: study of ten cases. J Am Acad Dermatol 1991; 24: $17-22$.

9. Da Silva Manzoni AP, Viecili JB, de Andrade CB, Kruse RL, Bakos L, Cestari TF. Acute hemorrhagic edema of infancy: A case report. Int J Dermatol 2004; 43: 48-51. 